\title{
\begin{tabular}{|l|l|l}
\hline & Jurnal Kependidikan Dasar & $\begin{array}{l}\text { Volume. } 1 \\
\text { Nomor. 1 } \\
\text { Tahun. } 2016\end{array}$ \\
\hline
\end{tabular}
}

\section{Desain Pedoman Praktikum Kimia yang Berorientasi Keterampilan Proses}

\author{
Syaiful Arif \\ Tarbiyah IAIN Ponorogo \\ arif_indri10@yahoo.com
}

\begin{abstract}
Abstrak
Pedoman praktikum kimia berbasis eksperimen SMA/MA kelas XI semester genap merupakan perangkat pembelajaran di laboratorium yang sudah divalidasi oleh ahli isi/materi pelajaran kimia dan ahli media/desain pembelajaran. Pengembangan ini bertujuan untuk (1) Untuk mendeskripsikan kelayakan materi/isi buku panduan praktikum berbasis eksperimen yang dikembangkan (2) untuk mendeskripsikan kelayakan kontruksi/desain buku panduan praktikum yang berbasis eksperimen. Rancangan penelitian mengunakan 4-D ( four D Models) yang terdiri dari tahap pendefinisian (define), tahap perancangan (design), tahap pengembangan (develop), penyebaran (desseminite). Kriteria panduan praktikum dinyatakan layak jika penilaian terhadap buku panduan diperoleh $\geq 61$ $\%$. Instrument penelitian yang digunakan adalah lembar validasi dan angket, lembar validasi digunakan untuk memberikan tanggapan dan penilaian terhadap panduan praktikum kimia yang dikembangkan. Lembar validasi ini diberikan kepada tim ahli isi/materi pelajaran kimia dan tim ahli media/desain pembelajaran. Sedangkan lembar angket diberikan kepada guru dan siswa pada saat ujicoba terbatas, angket ini digunakan untuk mengetahui respon siswa dan guru tentang buku panduan praktikum yang dikembangkan. Data yang diperoleh diolah berdasarkan skala likert didapatkan bahwa (1) kelayakan panduan praktikum kimia dari segi ahli isi/materi pelajaran diperoleh rata-rata sebesar 78,15 \%, yang artinya memenuhi dan layak untuk di ujicobakan (2) kelayakan panduan praktikum kimia dari segi ahli media/desain pembelajaran diperoleh rata-rata sebesar 80,98 \% yang artinya memenuhi dan layak untuk di ujicobakan (3) hasil angket respon guru kimia diperoleh rata-rata sebesar $84 \%$ yang artinya sangat memenuhi dan mudah penggunaannya (4) hasil angket respon siswa diperoleh rata-rata sebesar 79,3\% yang artinya memenuhi dan menarik dan mudah dipergunakan.
\end{abstract}

Kata Kunci: Pedoman praktikum kimia, Ahli isi/materi pelajaran kimia, Ahli media/desain pembelajaran.

\section{A. PENDAHULUAN}

Pendidikan sangat berperan sekali dalam kemajuan sumber daya masyarakat. Maju tidaknya pembangunan di suatu negara dapat dilihat dari bagaimana mutu pendidikan yang ada di suatu negara tersebut. Berbagai usaha telah ditempuh pemerintah untuk meningkatkan mutu pendidikan salah satunya adalah penyempurnaan kurikulum. Kurikulum merupakan unsur yang strategis dalam pendidikan sekolah, oleh karena itu arah 
perkembangan kurikulum harus berbasis kepada pengembangan potensi manusia.

Kurikulum yang di dalamnya mengandung Standar Kompetensi, Kompetensi Dasar dan Indikator yang menunjukkan seberapa jauh ketercapaian peserta didik terhadap materi yang dituntut dalam kurikulum. Untuk mengetahui pencapaian tersebut, salah satu alat yang digunakan adalah penilaian berbasis kelas (classroom based assessment) dalam kurikulum tersebut memberikan kontribusi yang sangat positif bagi dunia pendidikan, karena di dalamnya mengembangkan keterampilan, sikap dan nilai ilmiah serta memberikan pengalaman kepada siswa dalam merencanakan kerja ilmiah. ${ }^{1}$

Kurikulum menuntut seorang guru untuk melakukan perbuatan, tindakan dan sikap secara ilmiah. Keterampilan proses ilmiah yang dilatihkan antara lain menggolongkan, mengukur, menggunakan alat, mengkomunikasikan dengan berbagai cara lisan tulisan, diagram, menafsirkan, memprediksi, menganalisis, mensintesis dan melakukan percobaan secara terstruktur. ${ }^{2}$

Keterampilan-keterampilan tersebut di atas yang menjadi penggerak dalam mengembangkan fakta dan konsep serta menumbuh kembangkan sikap dan nilai. Laboratorium merupakan tempat proses belajar mengajar dengan menggunakan metode praktikum, melalui praktikum

\footnotetext{
${ }^{1}$ Sumarna Surapranata dan Mohammad Hatta, Pedoman Pengembangan Penilaian Portofolio (Jakarta: Pusat Penilaian Pendidikan badan Penelitian dan Pengembangan Departemen Pendidikan Nasional, 2006).

${ }^{2}$ Depdiknas, "Kurikulum Berbasis Kompetensi Standar Kompetensi Mata Pelajaran Sains SMP dan MTs" (Depdiknas, 2003).
}

siswa diharapkan mendapatkan pengalaman belajar melakukan suatu penelitian dengan menggunakan alat dan bahan yang tersedia untuk membuktikan suatu hipotesis atau teori secara langsung.

Laboratorium berfungsi sebagai sarana mengaplikasikan berbagai konsep yang telah didapatkan siswa dalam kegiatan pembelajaran, mengembangkan berbagai ketrampilan/kinerja, menerapkan metode ilmiah, dan membiasakan diri melakukan penelitian secara mandiri. Melalui kegiatan laboratorium siswa dapat mempelajari fakta, gejala, merumuskan konsep, prinsip, hukum dan sebagainya. Tujuan kegiatan praktikum selain untuk memperoleh pengetahuan yang bersifat kognitif juga bertujuan untuk memperoleh ketrampilan/kinerja, dapat menerapkan pengetahuan dan ketrampilan tersebut pada situasi baru/lain serta memperoleh sikap ilmiah. ${ }^{3}$

Untuk mendukung pelaksanaan kegiatan pembelajaran kurikulum tingkat satuan pelajaran yang substansinya merupakan perwujudan dari tujuan pendidikan nasional, maka digunakan sebagai sumberbelajar yang mendukung pelaksanaan kurikulum ini, salah satunya adalah buku pedoman praktikum. Buku pedoman ini menggunakan standart buku ajar menurut Badan Standar nasional Pendidikan (BNSP). Standar tersebut terdiri dari komonen kelayakan isi, komponen kebahasaan, dan komponen

\footnotetext{
${ }^{3}$ Utiya Azizah, "Penilaian Kinerja Praktikum dan Penyusunan Laporan Praktikum" (pelatihan ketrampilan menejemen laboratorium kimia bagi guru/laboran di lingkungan SMA, Surabaya: LPM Unesa, n.d.).
} 
penyajian. Ketiga komponen beserta cakupannya harus terpenuhi. Kelayakan isi meliputi cakupan materi, akurasi materi, kemutahiran, merangsang keingintahuan, mengandung wawasan keingintahuan, mengembangkan kecakapan hidup, mengembangkan wawasan kebhinekaan. Kelayakan bahasa meliputi; kesesuaian dengan perkembangan perkembangan peserta didik, komunikatif, dialogis, dan interaktif, lugas, koherensi, dan kebahasaan, kesesuaian dengan kaidah bahasa Indonesia, dan konsisten dengan istilah atau simbol. Kelayakan yang terahir adalah penyajian meliputi ; teknik penyajian, pendukung penyajian materi, penyajian pembelajaran. (BNSP, 2007) 4

Beberapa tuntutan dalam pembelajaran kimia diantaranya siswa harus mempunyai keterampilan ilmiah melalui kegiatan laboratorium. Melalui kegiatan laboratorium siswa belajar mendalami teori dengan mencoba langsung atau eksperimen. Keadaan demikian dipandang perlu merancang bahan ajar yang dapat membantu siswa maupun guru dalam proses pembelajaran di laboratorium. Kegiatan praktikum dapat membawa peserta didik mengalami proses berfikir, karena dari kegiatan inilah peserta didik mengalami proses berfikir, karena dari kegiatan inilah peserta didik berhadapan langsung dengan suatu masalah yangberhubungan dengan materi pelajaran dan diberikesempatan untuk memecahkan masalah tersebut,sehingga peserta didik dapat lebih mudah

\footnotetext{
${ }^{4}$ BNSP, "Instrumen Kelayakan Buku Ajar SMA/MA" (Depdiknas, 2007).
}

memahami materi pelajaran yang diberikan $^{5}$.

Kenyataan dilapangan menunjukkan bahwa secara umum buku buku kimia yang beredar saat ini sudah memasukkan sebagian besar kriteriakriteria kelayakan BNSP, khususnya materi pada semester genap, Namun dari sekian banyak buku yang didalamnya tidak semua mencantumkan petunjuk prkatikum di laboratorium dengan detail dan luas sehingga sulit dipahami, dan bahkan kegiatan laboratorium kurang sistematis. Berdasarkan uraian di atas peneliti ingin mengembangkan pedoman laboratorium kimia untuk SMA / MA yang berorientasi keterampilan proses.

Penelitian ini bertujuan untuk mengetahui kelayakan materi, kelayakan kontruksi, kelayakan bahasa, dan respon guru dalam mengggunakan pedoman laboratorium kimia SMA / MA kelas XI semester genap yang berorentasi pada keterampilan proses. Pentingnya produk pedoman praktikum kimia yang diharapkan adalah dapat mengatasi ketersediyaan bahan ajar kimia yang dapat mempermudah pembelajaran kimia di laboratorium, Menjadi salah satu sumber belajar yang diharapkan memberikan kemudahan bagi guru dan siswa dan dapat memperlancar proses pembelajaran kimia di sekolah.

\section{B. METODOLOGI PENELITIAN}

Model penelitian yang digunakan dalam pengembangan pedoman

\footnotetext{
${ }^{5}$ Reza Arsika, "pengembangan buku petunjuk praktikum Ipa Fisika untuk meningkatkan motifasi belajar siswa kelas VII SMPN 1 lembar tahun pelajaran 2014/2015" 1 (2015): 11 .
} 
praktikum kimia SMA/MA kelas XI adalah model pengembangan perangkat 4-D (Four D Models) model yang dikembangkan oleh Thiagarajan, Semmel dan Semmel, yang terdiri dari 4 tahap pengembangan yaitu: (1) pendefinisian (define), (2) perancangan (design), (3) pengembangan (develop), dan (4) penyebaran (disseminate). ${ }^{6}$ model pengembangan secara skematis seperti di bawah ini:

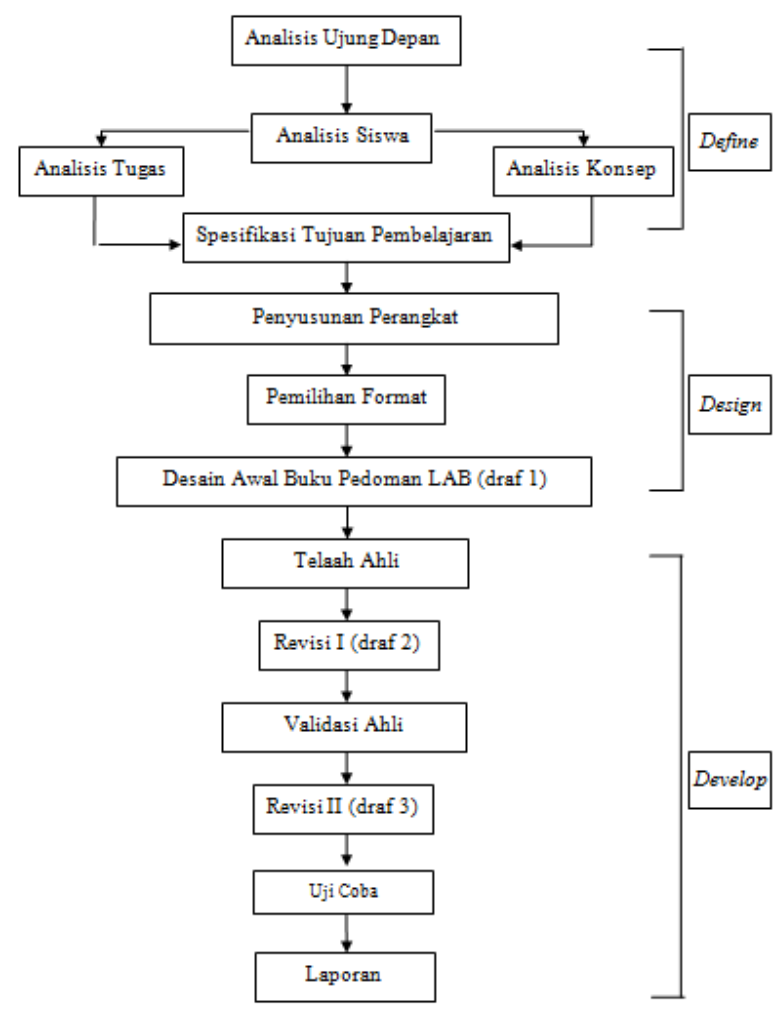

Gambar 1. Adaptasi dari Model Pengembangan Perangkat Pembelajaran 4-D Model Menurut Thiagarajan, Semmel dan Semmel. ${ }^{7}$

\footnotetext{
${ }^{6}$ Muslimin Ibrahiim, Model Pengembangan Perangkat Pembelajaran Meurut Jerold E. Kemp dan Thiagarajan (Surabaya: Pusat Sains dan Matematika Sekolah Unesa., 2002).

${ }^{7}$ Ibid.
}

Prosedur penelitian dalam pengembangan pedoman praktikum kimia SMA/MA terdiri dari empat tahap:

1. Tahap Pendefinisian (Define)

Tahap define ini bertujuan untuk menetapkan dan juga mendefinisikan syarat-syarat penyusunan pedoman praktikum kimia SMA/MA semester genap, yang meliputi sub tahap sebagai berikut :

a. Analisis ujung depan (Front end analysis)

Pada tahap ini bertujuan untuk mengangkat masalah dasar yang perlu untuk dikembangkan dalam pengembangan pedoman praktikum kimia SMA/MA. Pengembangan perangkat tidak lepas dari tuntutan kurikulum sains SMA/MA. Dalam kurikulum tingkat satuan pendidikan disebutkan ada empat pilar yang menjadi pertimbangan yaitu : Belajar untuk mengetahui (learning to know), belajar melakukan (learning to do), belajar untuk diri sendiri (learning to be), belajar untuk kebersamaan (leraning to live together). ${ }^{8}$

b. Analisis Siswa

Analisis siswa dilakukan dalam rangka mengetahui potensi atau kemampuan siswa, pengalaman dalam belajar, usia, kebiasaan, atau kecenderungan dari siswa. masa - masa seusia anak SMA/MA merupakan masa transisi. Sehingga siswa lebih cenderung mengarahkan kemampuan bernalarnya yang berhubungan dengan hal-hal yang nyata dan kongkrit. Dari pengalaman seorang guru yang mengajar kemampuan

\footnotetext{
${ }^{8}$ Depdiknas, "Kurikulum Berbasis Kompetensi Standar Kompetensi Mata Pelajaran Kimia" (Depdiknas, 2002).
} 
dan kesiapan guru untuk mengembangkan pedoman praktikum.

c. Analisis Tugas

Analisis tugas merupakan sistematika untuk menentukan isi satuan pelajaran. Sehingga dapat dijelaskan secara garis besar mengenai hal - hal yang berkaitan dengan bahan ajar, mengidentifikasi tugas - tugas yang perlu dilakukan siswa selama pelaksanaan kegiatan pembelajaran, praktikum, keterampilan dalam menggunakan alat, keterampilan mengumpulkan informasi dan membuat laporan.

d. Analisis Konsep

Analisis konsep dilakukan dengan mengidentifikasi konsep - konsep utama yang akan dipelajari siswa, yang tersusun secara sistematis dan terinci.. Kosep konsep tersebut dijadikan dasar untuk menentukan pokok bahasan yang harus dikuasai oleh siswa.

e. Perumusan Tujuan

Pada sub bab tahap ini hasil analisis tugas dan analisis konsep menjadi indikator hasil belajar. Meteri pokok Kimia SMA/MA dapat disusun indikator hasil belajar.

2. Tahap Perancang (Design)

Tahap perancangan dilakukan untuk menyusun dan merencanakan pedoman praktikum kimia SMA/MA Kelas XI semester genap, dengan langkah langkah yang akan dilakukan sebagai berikut :

a. Penulisan pedoman praktikum kimia SMA/MA Kelas XI semester genap.

Dasar dari penyusunan pedoman praktikum SMA/MA kelas XI semester genap adalah analisis konsep, analisis tujuan, dan tujuan pembelajaran. b. Pemilihan Kegiatan

Kegiatan yang dipilih sesuai dengan perumusan indikator pada tahap pendefinisian, sehingga diperoleh kegiatan siswa adalah:

Kegiatan Larutan asam - basa, Pembuatan indikator dari zat warna pada tumbuhan, Trayek perubahan warna indikator, Mengukur $\mathrm{pH}$ asam basa kuat dan asam basa lemah, Titrasi Asam - basa, Larutan Penyangga, Hidrolisis garam, Keadaan jenuh Suatu larutan, Efek Tyindall, Pembuatan koloid ${ }^{9}$

c. Pemilihan Alat dan Bahan

Alat dan bahan yang digunakan untuk menunjang pelaksanaan praktikum disesuaikan jenis tugas yang dikerjakan siswa.

3. Tahap Pengembangan (Develop)

Tahap ini bertujuan untuk menghasilkan pedoman praktikum kimia SMA/MA kelas XI semester genap yang telah direvisi berdasarkan masukan para penilai ahli dan masukan guru.

4. Penyebaran (Desseminate)

Pada tahap ini perangkat yang telah tervalidasi dengan baik diperbanyak dan disebar luaskan kepada pengguna untuk diimplementasikan dalam kegiatan belajar mengajar.

Dalam upaya mengetahui tingkat kemenarikan dan keefektifan produk pedoman praktikum dilakukan serangkaian uji coba terhadap produk tersebut dan kemudian diadakan revisi. Produk yang dihasilkan di ujicobakan melalui beberapa tahapan antara lain:

\footnotetext{
${ }^{9}$ Michael Purba, Kimia SMA Kelas XI (Jakarta: Erlangga, 2004).
} 
a. Tinjauan ahli isi/materi mata pelajaran, bertujuan untuk mendapatkan data berupa penilaian, pendapat, dan saran terhadap ketepatan isi buku pedoman laboratorium yang dikembangkan.

b. Tinjauan ahli desain/kontruksi, bertujuan untuk mendapatkan penilaian dan komentar serta saran terhadap ketepatan desain buku pedoman laboratorium yang dikembangkan.

c. Tinjauan ahli bahasa / media bertujuan untuk mendapatkan penilaian dan komentar serta saran terhadap ketepatan media buku pedoman laboratorium yang dikembangkan

d. Ujicoba kelompok. Penilaian kelompok mempunyai dua maksud. Pertama adalah menentukan keefektifan perubahan yang telah dibuat menyusul dilangsungkannya penilaian, maksud yang ke dua adalah menentukan apakah siswa dapat menggunakan pedoman praktikum itu tanpa adanya interaksi guru.

Uji coba dilakukan pada kelompok kecil siswa kelas XI SMA. ${ }^{10}$ dalam uji coba produk pengembangan ini bertujuan untuk mengidentifikasi dan mengurangi kesalahan kesalahan nyata yang terdapat buku pedoman laboratorium.

Pengumpulan data menggunakan instrument berupa angket dan tes, angket digunakan untuk mengumpulkan data hasil review dari ahli isi mata pelajaran, ahli media pembelajaran, data dari ahli desain pembelajaran, data dari siswa saat

\footnotetext{
${ }^{10}$ Ujicoba dilaksanakan di MAN 6 Jombang kelas XI IPA
}

uji coba perorangan, data saat uji kelompok.

Analisis data tiap komponen baik data hasil penilaian ahli, data hasil penilaian perorangan data hasil penilaian kelompok dan data hasil penilaian siswa dilakukan analisis deskriptif berupa rerata dan persentase. Dalam pengembangan ini validasi berdasarkan tiga kriteria yaitu materi, kontuksi dan bahasa. Nilai yang diberikan oleh valiadator untuk masing masing telah ditentukan skala penilaiannya sebagai berikut :

$$
\begin{aligned}
& 1=\text { Sangat kurang } \\
& 2=\text { Kurang } \\
& 3=\text { Cukup } \\
& 4=\text { Baik } \\
& 5=\text { Sangat baik }
\end{aligned}
$$

Tingkat pencapaian dengan menggunakan rumus :

$$
\text { Persentase }=\frac{\sum(\text { jawaban } \times \text { bobot tiap pilihan })}{n \times \text { bobot tertinggi }} \times 100 \%
$$

Perangkat portofolio yang dikembangkan dinyatakan memenuhi kriteria materi, kontruksi dan bahasa jika persentase nilai yang diperoleh dari analisis data adalah $\geq 61 \% .{ }^{11}$

\begin{tabular}{|l|l|}
\hline Skor & \multicolumn{1}{|c|}{ Kriteria persepsi } \\
\hline $\begin{array}{l}\text { 0\% - } \\
20 \%\end{array}$ & Sangat tidak memenuhi \\
\hline $21 \%-$ & Tidak memenuhi \\
$40 \%$ & \\
\hline $41 \%-$ & Kurang memenuhi \\
\hline
\end{tabular}

\footnotetext{
${ }^{11}$ Riduwan, Skala Pengukuran Variabel Penelitian (Jakarta: Alfabeta, 2003).
} 


\begin{tabular}{|l|l|}
\hline $60 \%$ & \\
\hline $61 \%-$ & Memenuhi \\
$80 \%$ & \\
\hline $81 \%-$ & Sangat memenuhi \\
$100 \%$ & \\
\hline
\end{tabular}

Tabel 1:Kriteria skala Likert ${ }^{12}$

Adapun cakupan data dalam

penelitian ini yaitu:

1. Data penilaian tanggapan ahli Isi dan ahli desain

2. Data penilaian Tanggapan perorangan

3. Data penilaian / tanggapan uji coba kelompok kecil

\section{PEMBAHASAN}

Dalam pengembangan pedoman praktikum kimia kelas XI IPA SMA/MA menggunakan model 4-D ( four D Models) menurut Thiagarajan, Semmel dan Semmel yang terbatas hanya pada tiga tahap yaitu tahap pendefinisian (define), tahap perancangan (design), tahap pengembangan (develop). 13

1. Tahap pendefinisian (define)

Tahap pendefinisian meliputi analisis ujung depan, analisis siswa, analisis tugas, analisis pokok bahasan dan spesifikasi tujuan pembelajaran. Berikut ini dijabarkan langkah - langkah pokok dalam tahap pendefinisian.

a. Analisis ujung depan

Analisis ujung depan dilakukan dengan memperhatikan kurikulum yang berlaku, teori belajar, dan tuntutan masa

\footnotetext{
${ }^{12}$ Ibid.

${ }^{13}$ Ibrahiim, Model Pengembangan Perangkat Pembelajaran Meurut Jerold E. Kemp dan Thiagarajan.
}

depan. Berdasarkan kajian terhadap kurikulum yang perlu dipertimbangkan dalam pembelajaran sains adalah :

1) Tiga pilar pendidikan diantaranya; belajar untuk mengetahui llearning to know), belajar melakukan (learning to $d o$ ), belajar untuk menjadi diri sendiri (learning to be), dan belajar untuk kebersamaan (learning to live toghether). ${ }^{14}$ Empat pilar belajar di atas masih harus didukung dengan sistem penilaian otentik yang artinya penilaian tidak hanya dilakukan di akhir pembelajaran, tetapi dilakukan terintegrasi dari kegiatan pembelajaran yang berarti kemajuan siswa juga dinilai dari proses.

2) Adanya pemberian pengalaman belajar secara langsung, melatih keterampilan proses dan sikap ilmiah. Hal ini dapat dilakukan dengan memberikan percobaan/praktikum kepada siswa.

3) Penilaian hendaknya dilakukan selama proses pembelajaran dan mampu menilai aspek psikomotor, afektif dan kognitif.

b. Analisis siswa

Dalam tahap ini menelaah tentang karakteristik siswa yang sesuai dengan rancangan dan pengembangan panduan praktikum kimia.

b.1 tingkat perkembangan intlektual (operasional formal)

Siswa SMA/MA berusia 16 tahun memiliki perkembangan kognitif yang diketahui Peaget disebut operasional formal, yaitu periode berfikir tentang rencana masa depan dan peranan orang

\footnotetext{
${ }^{14}$ Depdiknas, "Pedoman Pengembangan Penilaian Portofolio" (Depdiknas, 2006).
} 
dewasa mulai kecakapan penanganan secara logis situasi serta individu dapat bernalar dari situasi rekaan menjadi nyata (Nur, 1999). Hal ini berarti pedoman praktikum kimia kelas XI yang dikembangkan harus memiliki dua dimensi nalar, yaitu teori teori yang bersifat abstrak dan teori - teori kongkrit. Serta semua tujuan dari materi mengarah pada masa depan, jika materi ini rencana masa depan yang dimaksud adalah penguasaan ilmu pengetahuan dan teknologi.

b.2 Tingkat perkembangan sosio emosional

Tingkat perkembangan sosio emosional merupakan perkembangan mental atau jiwa dalam hubungannya dengan lingkungan fisik. Pada pengembangan ini komponen perkembangan sosio emosional yang diambil sebagai berikut:

a) Kemampuan siswa

Siswa SMA/MA sudah matang dalam melakukan sesuatu, dengan berfikir terlebih dahulu sebelum bertindak. Tetapi kemampuan untuk membuktikan fenomena ilmu pengetahuan kimia memerlukan bantuan guru/media untuk membuktikannya di laboratorium kimia.

b) Pengaruh sosial

Dari hasil observasi, bahwa siswa SMA/MA selama berada di sekolah hubungan antara guru dan siswa terjalin dengan sopan, hal ini mendukung adanya pengembangan pedoman praktikum kimia kelas XI yang didalamnya termasuk ada nilai nilai ketrampilan sosial, sehingga perlu adanya fitur buku yang mengarah pada keterampilan ibi, fitur yang dimaksud dapat berupa demonstrasi, diskusi, dan tugas lain yang mengarah pada kooperatif.

c) Lokasi belajar

Lokasi belajar sangat menentukan menentukan hasil belajar siswa. Lokasi belajar dalam hal ini tentunya di laboratorium, sehingga pedoman praktikum yang dikembangkan menyesuaikan tempat belajar siswa.

d) Perumusan indikator pembelajaran

Indikator hasil belajar dalam semester genap untuk masing - masing percobaan adalah sebagai berikut :

- Siswa dapat membedakan larutan asam dan basa dengan menggunakan lakmus.

- Siswa dapat menjelaskan cara pembuatan larutan indikator dari tumbuhan - tumbuhan.

- Siswa dapat menentukan trayek pH beberapa indikator asam basa

- Siswa dapat membandingkan pH asam basa kuat dan asam basa lemah

- Siswa dapat menentukan konsentrasi larutan asam oleh basa

- Siswa dapat membedakan perubahan pH larutan penyangga

- Siswa dapat menentukan sifat larutan garam yang berasal dari asam lemah dan basa kuat serta larutan garam tang berasal dari asam kuat dan basa lemah.

- Siswa dapat mengamati keadaan jenuh sustu larutan

- Siswa dapat membandingkan kelarutan suatu garam atau basa sukar larut dalam air dan dalam berbagai larutan yang mengandung ion sejenis .

- Siswa dapat membedakan suspensi, koloid dan larutan sejati

- Siswa dapat menunjukkan sifat sifat yang khas yaitu efek tyndall 
- Siswa dapat menunjukkan sifat sifat yang khas yaitu Koagulasi koloid .

Siswa dapat menjelaskan cara pembuatan koloid dengan cara kondensasi dan dispersi 15

2. Tahap Perancangan (Design)

Tujuan dari tahap ini adalah mendesain awal pedoman praktikum. Tahap perancangan dilakukan untuk merencanakan dan menulis pedoman praktikum kimia serta pemilihan format. Tahapan - tahapan dalam perencanaan adalah sabagai berikut :

a. Penyusunan pedoman praktikum kimia

Pada tahap ini meliputi pemilihan kegiatan siswa, pemilihan alat dan bahan, dan penyusunan evaluasi tugas siswa. Kegiatan yang dipilih dan disesuaikan dengan perumusan indikator yang sesuai dengan tahap pendefinisian, sehingga diperoleh percobaan yaitu: Larutan asam basa, Pembuatan indikator dari zat warna pada tumbuhan, Trayek perubahan warna indikator, Mengukur pH asam basa kuat dan asam basa lemah, Titrasi Asam - basa, Larutan Penyangga, Hidrolisis garam, Keadaan jenuh suatu larutan, Kelarutan dan hasil kelarutan natrium hidroksida, Sistem Koloid, Efek Tyindall, Koagulasi Koloid, Pembuatan koloid. ${ }^{16}$

b. Penyusunan format

Pemilihan format pedoman praktikum kimia yang di gunakan dalam pengembangan kali ini adalah dikembangkan sendiri oleh peneliti untuk keperluan pengembangan, dari tiap-tiap

\footnotetext{
${ }^{15}$ Indikator dikembangkan peneliti sesuai dengan pokok bahasan di kelas XI

${ }^{16}$ Purba, Kimia SMA Kelas XI.
}

percobaan mempunyai format garis besar berupa:

1) Caver percobaan: berisikan ilustrasi gambar yang disesuaikan dengan percobaan masing - masing judul dan terdapat standar kompetensi, kompetensi dasar, dan indikator hasil percobaan.

2) Pendahuluan: berisi uraian dasar teori yang mendukung dari masing - masing percobaan yang bersifat singkat dan sederhana.

3) Alat dan bahan: berisi daftar alat - alat dan bahan - bahan yang akan digunakan dalam percobaan tersebut.

4) Langkah percobaan: berisi tahapan dan urutan selama melakukan percobaan yang menggunakan kalimat aktif dari tiap langkah.

5) Hasil pengamatan: berisi tabulasi hasil percobaan yang dilakukan berupa data data kongkrit hasil percobaan.

6) Evaluasi: berisi pertanyaan pertanyaan untuk menguji pemahaman siswa dari hasil percobaan yang sudah dilakukan.

7) Tindak lanjut dan penerapannya: berisi pertanyaan yang disesuaikan dengan bukti atau kejadian yang ada di lapangan sehingga peserta didik bisa menghubungkan hasil yang ada dengan lingkungan sekitar.

3. Tahap pengembangan

Tujuan dari tahap pengembangan adalah untuk mengembangkan pedoman praktikum sesuai dengan perencanaan yang ada. Agar menjadi pedoman yang baik perlu ada penilaian dari beberapa ahli yaitu ahli desain pembelajaran, ahli isi materi pelajaran dan guru. 
a) Validasi

Tahap validasi ini dilakukan untuk mengetahui kelayakan pedoman prkatikum kimia yang dikembangkan. Berdasarkan saran dan masukan dari validator dilakukan revisi untuk menghasilkan pedoman praktikum yang layak.

b) Revisi

Tahap revisi dilakukan utuk menghasilkan draf yang merupakan pedoman final yang sudah tervalidasi dan layak untuk digunakan.

Data yang di paparkan secara berurutan adalah data berupa tanggapan dari ahli isi mata pelajaran, ahli desain dan media, dan hasil angket uji coba kelompok, serta angket guru mata pelajaran kimia. Setelah itu dipaparkan analisis data di ikuti revisi produk yang dikembangkan, berikut sajiannya:

1. Uji Ahli Isi/materi Mata Pelajaran

Berdasarkan rekapitulasi data dari ahli isi mata pelajaran kimia diperoleh rata - rata prosentase keseluruhan tiap percobaan adalah 78,15 \%. Jika di konversikan dengan tabel skala penilaian kelayakan produk prosentase tingkat $78,15 \%$ berada pada kualifikasi memenuhi, yang artinya pedoman praktikum kimia kelas XI semester genap yang dikembangkan sudah layak untuk di ujicobakan.

2. Uji Ahli Desain dan Media

Berdasarkan rekapitulasi data dari ahli desain/media pembelajaran dengan kriteria penilaian berupa : halaman judul, petunjuk keamanan Lab, kerangka isi, standar kompetensi, kompetensi dasar dan indikator hasil belajar, uraian materi, gambar, teks (Intisari Materi), evaluasi/latihan dan tindak lanjut, sumber pendukung dengan perolehan rata - rata prosentase keseluruhan tiap aspek sebesar 80,98 \%. Jika di konversikan dengan tabel skala penilaian kelayakan produk prosentase tingkat 80,98\% berada pada kualifikasi memenuhi, yang artinya pedoman praktikum kimia kelas XI semester genap yang dikembangkan sudah layak untuk di ujicobakan.

3. Hasil Angket Respon Guru Kimia

Berdasarkan rekapitulasi data dari guru mata pelajaran kimia, diperoleh prosentase $84 \%$. Jika di konversikan dengan tabel skala penilaian kelayakan produk prosentase tingkat $84 \%$ berada pada kualifikasi memenuhi, yang artinya pedoman praktikum kimia kelas XI semester genap yang dikembangkan dan di ujicobakan secara umum mudah di pergunakan dan sangat membantu sekali pembelajaran di laboratorium.

4. Hasil Angket Respon Siswa

Berdasarkan rekapitulasi data dari siswa diperoleh rata - rata prosentase tiap siswa 79.3 \%. Jika di konversikan dengan tabel skala penilaian kelayakan produk prosentase tingkat 79,3 \% berada pada kualifikasi memenuhi, yang artinya panduan praktikum kimia kelas XI semester genap yang dikembangkan dan di ujicobakan secara umum mudah di pergunakan,petunjuknya jelas, menarik, dan mudah dipahami.

\section{PENUTUP}

Setelah di validasi oleh ahli isi/materi matapelajaran, ahli desain dan ahli media pembelajaran dan di ujicobakan dilapangan dalam kelompok terbatas, semua masukan dicatat untuk revisi 
terhadap pedoman praktikum yang dikembangkan. Ahli isi/materi pelajaran memberikan penilaian rata-rata 78,15 \%, sahli desain dan media pembelajaran memberikan penilaian rata-rata $80,98 \%$, guru materi pelajaran kimia $84 \%$, sedangkan angket respon siswa menyatakan $79,3 \%$, yang artinya pedoman praktikum layak untuk di ujicobakan, dan di kembangkan.

Beberapa masukan memberikan kekuatan dan kelemahan terhadap produk yang dikembangkan. Adapun kekuatan yang di berikan , (1) produk yang disusun secara sistematis untuk digunakan guru dan siswa dalam kegiatan laboratorium, (2) panduan praktikum yang dikembangkan dapat digunakan tanpa kehadiran guru di laboratorium, dan diharapkan siswa membaca terlebih dahulu petunjuk penggunaan dan alur kerja, (3) panduan praktikum yang dikembangkan menyajikan rangkuman materi, prosedur percobaan evaluasi dan tindak lanjut penerapan (4) bahasa yang digunakan dalam penulisan panduan praktikum kimia adalah bahasa semi formal. Sedangkan kelemahan dari panduan praktikum kimia yang dikembangkan adalah disusun berdasrkan karakteristik siswa kelas XI semester genap MAN 6 Jombang sehingga penggunaan untuk siswa lain perlu penyesuaian.

\section{E. DAFTAR PUSTAKA}

Arikunto, Suharsini. Dasar-dasar Evaluasi pendidikan (Edisi Revisi). Jakarta : Bumi Akasara. 2003

Azizah, Utiya. "Penilaian Kinerja Praktikum dan Penyusunan
Laporan Praktikum". Makalah disampaikan dalam pelatihan ketrampilan menejemen laboratorium kimia bagi guru/laboran di lingkungan SMA pada tanggal 20 - 27 september 2003 di LPM Unesa.

Arsika, Reza. "pengembangan buku petunjuk praktikum Ipa Fisika untuk meningkatkan motifasi belajar siswa kelas VII SMPN 1 lembar tahun pelajaran 2014/2015" 1 (2015): 11.

BNSP. "Instrumen Kelayakan Buku Ajar SMA/MA" Jakarta: Depdiknas, 2007.

Depdiknas. "Pedoman Pengembangan Penilaian Portofolio". Jakarta : Depdiknas, 2006.

Depdiknas. "Kurikulum 2006 Mata Pelajaran Kimia SMA/MA". Jakarta : Depdiknas, 2006.

Depdiknas. "Pedoman Penilaian Kelas 2004". Jakarta: Depdiknas, 2004.

Depdiknas. "Kurikulum Berbasis Kompetensi Standar Kompetensi Mata Pelajaran Sains SMP dan MTs". Jakarta: Depdiknas, 2003.

Depdiknas. "Standar Penilaian Buku Pelajaran Sains". Jakarta: Pusat Perbukuan Departemen Pendidikan Nasional, 2003.

Depdiknas. "Kurikulum Berbasis Kompetensi Standar Kompetensi Mata Pelajaran Kimia". Jakarta: Depdiknas, 2002.

Hamalik, Oemar. Kurikulum dan Pembelajaran. Jakarta: Bumi Aksara, 2005.

Ibrahim, Muslimin. Model Pengembangan Perangkat Pembelajaran Meurut 
Jerold E. Kemp dan Thiagarajan. Surabaya: Pusat Sains dan Matematika Sekolah Unesa, 2002.

Jatmiko. Penilaian Berbasis Kelas (PBK). Surabaya. Unesa, 2004.

Purba, Michael. Kimia SMA Kelas XI. Jakarta: Erlangga,. 2004.

Mulyasa. Kurikulum Berbasis Kompetensi Konsep, karakteristik, dan Implementasi. Bandung: PT Remaja Rosdakarya, 2005

Mulyasa, Implementasi Kurikulum 2004. Bandung: PT Remaja Rosdakarya, 2005

Nur, Mohammad dan Masitah. Perkembangan Peserta Didik. Surabaya. University Press Unesa,1999.

Nur, Mohammad. Pembelajaran dan Assemen IPA. Surabaya: Pusat Sains dan Matematika Sekolah Unesa, 2002

Purba, Michael. Kimia Untuk SMP Kelas VIII. Jakarta PT Erlangga, 2004

Setyosari, Punaji. Metode Penelitian Pendidikan dan Pengembangan. Jakarta : Kencana Prenada Group, 2010

Riduwan. Skala Pengukuran Variabel Penelitian. Jakarta: Alfabeta, 20003

Sudjana, Nana. 2004. Dasar - Dasar Proses Belajar Mengajar. Bandung : Sinar Baru Algensindo.

Surapranata, Sumarna dan Hatta Muhammad. Pedoman Pengembangan Penilaian Portofolio. Jakarta: Pusat Penilaian Pendidikan badan Penelitian dan Pengembangan Departemen Pendidikan Nasional, 2006.
Surapranata, Sumarna dan Hatta Muhammad. Penilaian Portofolio Implementasi Kurikulum 2004. Bandung: PT Remaja Rosdakarya, 2006

Surapranata, Sumarna. Pedoman

Pengembangan Penilaian Portofolio. Jakarta: Pusat Penilaian Pendidikan Badan Penelitian dan Pengembangan Depdiknas, 2006.

Suyono dan Amaria, 1993. Laporan Penelitian Uji Coba naskah Kuliah Kimia Dasar Untuk Pokok Bahasan Struktur Molekul. Surabaya: Pusat Penelitian IKIP Surabaya.

Tjokrodiharjo, S. Organisasi dan Manajemen Laboratorium Pendidikan IPA. Surabaya. 1987. 